\title{
Contingent High-Skilled Work and Flexible Labor Markets. Creative Workers and Independent Contractors Cycling Between Employment and Unemployment ${ }^{1}$
}

\author{
Pierre-Michel Menger*
}

\begin{abstract}
Flexibility in highly skilled jobs combines the characteristics of the secondary and the professional labor market, which oblige to revise the separation between salaried work and self-employment. Two cases are studied: the employment system of artists and technical workers in the performing arts and the work of independent contractors mediated by umbrella firms. An analysis of the French labor market shows how "flexicurity" may work, but also how its books may get unbalanced, as employers learn to make strategic use of unemployment insurance.
\end{abstract}

Keywords: performing arts, independent contractors, flexibility, unemployment insurance

\section{Flexibilität in hoch qualifizierten Jobs. Kunstschaffende und Freelance-Berater zwischen Anstellung und Arbeitslosigkeit}

Zusammenfassung: Flexibilität in hoch qualifizierten Jobs kombiniert die Eigenschaften des sekundären und des professionellen Arbeitsmarktes. Deshalb gilt es den Gegensatz zwischen Erwerbsarbeit und Selbständigkeit zu überdenken. Zwei Fälle werden vorgestellt - Künstler und Techniker der darstellenden Künste und Freelance-Berater für Dachgesellschaften. Die Analyse des französischen Falles zeigt, dass «Flexicurity-Mechanismen» Schutz gegen Arbeitslosigkeit bieten - aber Ungleichgewichte erzeugen, sobald die Arbeitgeber lernen, die Arbeitslosenversicherung strategisch zu nutzen.

Schlüsselwörter: darstellende Künste, Dachgesellschaften, Flexibilität, Arbeitslosenversicherung

\section{Travail atypique hautement qualifié sur des marchés flexibles. Les travailleurs des arts et les consultants indépendants entre emploi et chômage}

Résumé: La flexibilité dans les emplois très qualifiés cumule des caractéristiques du marché secondaire et du marché professionnel du travail, qui obligent à réviser l'opposition entre salariat et travail indépendant. Deux cas sont présentés - les artistes et techniciens des arts du spectacle et les consultants au sein de sociétés de portage salarial. L'analyse du cas français montre que les mécanismes de la "flexisécurité» décrite sont à la fois protecteurs et générateurs de déséquilibres, dès que les employeurs apprennent à faire un usage stratégique de l'assurance-chômage.

Mots-clés: arts du spectacle, portage salarial, flexibilité, assurance-chômage

\footnotetext{
* Collège de France, F-75005 Paris, pierre-michel.menger@college-de-france.fr.

1 I thank members of the guest editors of this issue, as well as two anonymous referees for helpful comments on a previous version of the paper. Colin Marchika provided invaluable assistance to collect and process the data used in this study. I also wish to thank Pierre Verschueren for his helpful suggestions.
} 
Labor flexibility usually refers to two different meanings and values. The first one is the so-called numerical flexibility, which requires substitutable workers to save labor costs and turn them increasingly in variable costs, up to the point where returns to flexibility become negative. Flexible labor management in that sense applies mainly to low-skilled workers, easy to hire and lay off. The other kind of flexibility is the so-called functional one that takes advantage of the core characteristics of professional work (autonomy, responsibility) and prevails in challenging, non-routine work situations (Stinchcombe 1959; Piore and Sabel 1984; Christopherson and Storper 1989). It should be noted that this flexibility conceals as one of its key components the constant requirement of learning and human capital acquisition: non-routine and autonomous work can be defined as true tied packages of work and learning. Usually, either of these flexibilities prevails in different sectors (Picart 2014).

But could it be that both flexibilities go together, although workers depicted by each differ radically? This question was raised ever since high quality resource management schemes began to be researched (Appelbaum et al. 2000). A fresher look at it comes from what we have learned from the innovation engine as the key factor of sustainable endogenous growth in the economy (Aghion and Howitt 2009). Knowledge, learning and intrinsic motivation, when they combine to favor idea generation and creativity at work, are today celebrated as the most powerful leverage to ensure growth and win the war against robots and machine learning (Brynjolfsson and McAfee 2014). Firms and markets want to know how to draw from what is supposed to be the ultimate inexhaustible source of growth, human creativity, both in its specialized form (that of professional work in the creative activities of workers such as scientists, researchers, engineers, artists) and in its more mundane manifestations, such as everybody's intelligent behavior at work.

The cultural sector is a remarkable hotbed of creativity, as it takes originality, inventiveness and autonomy at work to such high levels that it seems to overshadow the technical skills required for higher specialized activities. Since the 1990s, the cultural sphere started to be seen as a "creative industries" sector (Kerry and Chan 2014). ${ }^{2}$ Activities which can be defined as both utilitarian and functional forms of symbolic production came to be included, since they must be exercised with enough inventiveness to ensure a profitable quotient of originality and innovation: e.g. advertising, fashion, industrial and software design are good cases in point (Bakhshi

2 The movement started in Australia under the left-wing Keating government, which promoted the idea of a "creative nation" in the early 1990s (Bennett and Carter 2001). This revamped cultural policy had two main objectives: to work towards the complete recognition of multiculturalism and to promote the creative industries, whilst moving towards the information and communication technologies sector's industrial policy. In Europe, this doctrine was revised and implemented by Tony Blair's government from 1997 onwards (DCMS 1998, 2008; Hesmondhalgh and Pratt 2005) before spreading throughout the continent (Menger 2014b). 
et al. 2008; Potts 2011). Creativity thus became a generic part of the inventiveness common to all economic activities that constantly require knowledge, investment and skill complementarity to high tech in the production process, in order to ensure innovation and competitiveness. ${ }^{3}$

The consecration of key values associated with creativity in the work setting is one of the arguments of the creative industries' revamping policy: a flexible and compliant personal approach, an appetite for risk, the ability to cope with the unexpected, lateral and intuitive thinking, the championing of diversity within teams (Banks and Hesmondhalgh 2009). What do those jobs and employment markets promoting such qualities look like? Monographs on various European countries (Compendium 2012) invariably highlight the disparity between the vigorous growth of this employment sector on one side, far ahead of the service industry taken as a whole, and on the other side the individual situation of those who are in this job market: Educational qualifications are above average, but huge inequalities remain in earnings, as shown by the Paretian profile of their distribution (four fifths of earnings and amounts of work are enjoyed by less than one fifth of professionals). However they also value autonomy and a lack of routine in their work. Non-routine yields a higher learning content of work, which nurtures the sense of self-development and correlates with inventiveness. Artistic labor markets, now labelled as creative labor markets, are readily seen as forerunners in the implementation and development of highly skilled, functional flexibility. Their characteristics indicate the mainspring of an economy whose production of higher value-added goods and services is endlessly differentiated and varied.

Yet their impact on the employment situation represents a challenge for social policies, since variability in the work content and structural uncertainty of hiring prospects, both deriving from a project-based organization, decrease the odds of a sustainable career. Competition among workers is tougher, and the inter-temporal substitution of risk alleviation for reduced autonomy is by definition missing within a flexible scheme of fixed-term contractual work or freelancing. This is why artistic occupations have been experiencing not only all kinds of flexible work, but also a variety of management tools to mitigate occupational risk by means of individual diversification through multiple jobholding, collective resource pooling (via cooperative and group solidarity), income transfers (via unionization and social security), public support and private patronage (Menger 2006).

Admittedly, occupational risk in creative occupations is quite similar to that faced by all kinds of self-employed workers, as unemployment insurance compensation is beyond their reach. Yet public support to creative industries could take place by means of specific protection measures tailored to meet the idiosyncrasies of artistic

3 Ironically enough, this revamping process could occur even at the expense of its original source, the artistic sphere, when it came to redefine priorities on the political agenda (Bilton 2006; Oakley 2009; Pratt and Jeffcut 2009). 
careers. Evidence is quite mixed, however. Denmark, the champion of "flexicurity," does not grant artists special status, to ensure that all sectors are treated equally. The Netherlands trialled a long-term artists' wage scheme, but had to downgrade the scheme's ambitions radically in order to avoid overspending. The UK and Germany have implemented some special measures, with limited scope (Compendium 2012). France is an exception. No other country treats cultural employment as favorably as France: in the 1960s, this country had come up with a proposal for bridging the employment/unemployment gaps experienced by artists and workers in the performing arts sector (i.e. the live performing arts and the audio-visual and film industries). From the 1980s onward, that mechanism began to run at full speed, and the resulting combination of highly flexible employment and highly flexible compensation for interstitial unemployment spells has since played a major role in the boom of cultural supply in the French performing arts and media industry, by lowering labor costs and adjusting labor demand to the needs of a project-based organization of production.

The French system of risk management under a highly flexible employment scheme, although quite unique, might offer insights into actual challenges facing the various "welfarist" employment protection legislations. For economies experiencing rising contingent employment and cumulative innovations in the contractual arrangements (e.g. those set up by platform companies), the issue of devising sustainable risk management schemes is indeed of primary importance. Yet the combination of flexible project-by-project working patterns and the individual threat of recurrent under-employment may lead to overtaxing social welfare mechanisms, if they are internalized and pushed to the limit by employers and not properly regulated.

As I will show with this first case study, known as the "intermittent worker" model, for the last three decades the artistic flexicurity mechanism developed in France has been so successful in supporting the performing arts and media industry that the growth of employment has started to operate paradoxically. Labor demand in these industries has increased continuously, but compensated unemployment has grown even faster, in contrast to all the usually observed labor market trends. A closer look helps determine whether that intermittent contract scheme has turned out to be a quixotic experimentation. This employment system has been under recurrent reform pressure for the last three decades, each time arousing huge and dramatic public protests and strikes by artists as well as an enormous amount of experts' assessments and reports. Ironically enough, employers and their intermittent workforce have fought hand in hand in order to preserve the insurance scheme that allows the former to draw at will on a considerable pool of available workers and therefore to turn their fixed labor costs into entirely variable costs, while providing the latter with a sophisticated means to compensate for structural underemployment under piecemeal allocation of work. State political intervention overtly supports the scheme and has repeatedly interfered with social negotiations for three decades, 
in order to legitimize it as a component of the French cultural policy. At the same time, the successive governments have transferred the steadily increasing costs of this system to the social protection institutions that are devised and managed by employers and worker unions in order to mutualize only temporary deficits generated by sectorial imbalances.

Now if that system hadn't actually contributed to spread the risk of unemployment, which it is devised to protect against, by speeding up the fragmentation of employment and encouraging the dispersal of demand for work, it would make for a fine multipurpose model of social protection. One prominent feature of the French unemployment insurance regime for intermittent workers is its hybridization of legal contractual subordination and de facto free-lance autonomy. Self-employed workers usually have no access to unemployment insurance whose rules and allowances are tailored to protect standard salaried workers against redundancies. If the legal apparatus of employment protection succeeds in providing freelancers with protections designed for salaried workers, as is the case for French intermittent workers, the question arises whether such an intricate combination of salaried work and compensated unemployment may offer viable solutions to devise a welfarist management of flexibility, in other words, a sustainable flexicurity management scheme.

In the second part of the paper, I study the case of independent contract consulting via umbrella companies, which builds on a combination of high-skilled flexible work and unemployment benefits fairly similar to that of intermittent workers. Freelance consultants act overtly as independent contractors who obtain customers on their own to provide a service, with the umbrella company mainly playing the role of a third party provider of settlement services. If the observed combination of earnings and unemployment allowances notably raises the odds of developing one's activity, at least temporarily, lessons can be drawn from our case studies about the scope and sustainability of such flexicurity schemes.

Note that the rise of both intermittent work and contract work studied hereafter belongs to a much larger and quite impressive trend: the fragmentation of activities and, accordingly, of the increasingly frequent alternation between employment and unemployment. In 2013, more than a million jobseekers undertook a reduced activity every month: Almost one out of every two benefit recipients were working and looking for a job in the same month (Unédic 2013b). However, the workers I study in this article adopt a strategic use of the reduced activity scheme, since specific rules allow them to combine wages and benefits in a much less restrictive way than in the normal situation of reduced activity. ${ }^{4}$

$4 \quad$ The "reduced activity" scheme was introduced into the French Labor Law in 1951. Designed as an incentive to return to work, it allows jobseekers to take a job, even for a short period, at the same time as being registered as unemployed. An unemployment insurance package enables them, under certain conditions, to combine the salary from their monthly activity with a portion of their benefit. Those that either work longer than 110 hours or receive an income in excess of $70 \%$ of their previous salary do not receive benefits. Those rules evolve depending on the 
This paper focuses mainly on the interaction of work contingency and the unemployment insurance rules designed to shelter workers against the pervasive risk of underemployment and allow employers to draw on a pool of workers without incurring the entire cost of the flexicurity scheme that emerged.

The paper intends to contribute both to the sociology of employment and working conditions in the creative industries and to the literature on flexicurity. The case studies I present address the French labor market situation, and the potential for international comparisons is clearly limited by the peculiarities of national employment and social insurance legislations. However, the triangular relationship shaping the strategic interaction between employers, freelancers and the unemployment insurance agency that is carefully investigated herein is likely to provide a basis to extrapolate from. After a decade of growing interest and debate from the mid-1990s, the flexicurity label arose suspicion and critical discussion (Keune and Serrano 2014). The search for complementarity of flexibility and security now seems to gain a new relevance, due to the mounting speculations sparked off by job polarization and the disruptive effects of the platform economy rise on employment relationships. In that respect, I contend that work arrangements and the management of career uncertainty in the creative industries have much to teach us.

I exploit two unique data sets. ${ }^{5}$ My analysis of intermittent employment covers two decades of expansion of employment-unemployment system in the performing arts. Due to change in the construction of the data source that I used, I was unable to extend the analysis beyond 2007. The survey on contract work (Menger et al. 2007) is unique: It was conducted at a time when contract work through umbrella companies raised legal controversy. In each study, the data sets bring together data on the mechanics and quantities of work and unemployment compensation. To my best knowledge, no research has been conducted since on intermittent artistic work and on contract work operated by umbrella companies in France ${ }^{6}$, using the same kind of sources, methodology and matching data on employment and unemployment compensation.

way employers' organizations and workers' unions agree to manage the flexicurity dimension of labor market that leans on the UI system. The use of that scheme has developed since the 1990s, peaking from the late $2000 \mathrm{~s}$ on, due to a dramatic increase in short-term contracts and part-time work (Unédic 2013a, 2013b).

5 A full technical specification of the data sets is given in Menger (2011) and Menger, Costa and Hanet (2007).

6 During the past decade, a series of sociological studies has been devoted in France to the intermittent working system in the arts. Most proceed by qualitative survey. Among recent quantitative studies, those by Marchika et al. (2008), Cardon (2011) and Pilmis (2013) stand out. A small size survey was conducted in 2010 (Lenoir and Schechter 2011) with independent contractors. Although its results confirm ours, its scope is very limited. This is an indication of the difficulty to investigate systematically and repeatedly on non-standard employment configurations, for which official statistics is poorly equipped (see Katz and Krueger 2016, for comments on that point and an attempt to overcome the difficulty). 


\section{Dual flexibility and work organization}

The usual picture of organizational design and human resource management (HRM; see Appelbaum et al. 2000) fits the labor market segmentation theory by distinguishing between:

, secondary labor markets where flexibility, worker substitutability, skill transferability and fixed cost minimization through low-wage policy for low-skilled jobs are at their highest;

, internal labor markets developed by firms that emphasize low turnover and high productivity bear costs of screening, trying out and training, and use optimal reward schemes based on long-term contracts and tenured jobs;

professional labor markets for high-skilled workers who benefit from weak attachment to a firm, even if incorporated, and considerable bargaining power due to the high market value of their expertise and the high transferability of their skills (Kanter 1986; Baron and Kreps 1999).

That distinction roughly corresponds to the three segments of the labor market, as depicted by Freidson (1994). Interestingly enough, flexibility impacts mainly segments 1 and 3, those of secondary and professional labor markets. Yet flexibility assumes two very different meanings in those cases. The first kind of flexibility is numerical and it applies to type 1 jobs and workers' management. Workers are, or are regarded, as low-skilled and substitutable, and competition occurs through pricing of this low-skilled labor. Along with the increasing use of fixed-term contracts, a whole range of so-called "alternative work arrangements" has developed to optimize the labor cost lowering trend and reshape human resource management in order to face cyclical movements as well as technological changes in the economy (Katz and Krueger 2016; OECD 2016). As stated by Smith (1997, 326-327)

peripheral or contingent work force consists of temporary, part-time, seasonal and subcontracted workers... Employers able to draw on contingent workers avoid having workers on their payrolls when demand is slack; they reduce their wage and benefit costs when they have temporary or part-time workers on board and save by externalizing the administrative costs entailed with recruitment, hiring and control of temporary workers on different dimensions of flexibility that corporations attempt to gain by outsourcing.

But flexibility takes a different organizational meaning when it comes to flexible high-skilled workers (Kunda et al 2002). Professionals are endowed with high qualifications that have market values outside the firm on a national or international scale. To secure or improve their reputation, they rely on their skills as well as on opportunities to take on ever more challenging assignments that are likely to bring them greater knowledge and more rewards. In short, they have an external (national or international) market value based on reputation, and they exhibit multiple loyal- 
ties, to their organization, to their professional community (Sarfatti Larson 1977; Freidson 1994), and to the client organization, the differential strength of each kind of loyalty and its determinants being a matter of empirical identification (George and Chattopadhyay 2005).

One must bear in mind that like the workers in the secondary labor market, they are highly mobile, loosely tied to their employers, and like those in the internal labor market segment, they are skilled. But unlike low-skilled workers, mobility correlates with market value. What is more, unlike skilled workers in internal labor markets, their employability correlates with their ability to find skill-improving jobs and to optimally diversify their work experience in various settings, in order to keep their learning potential and reputation on track.

New management practices insistently refer to the core values of professional independence at work - autonomy, responsibility, self-control in teamwork, extended range of skills enhancing the sense of initiative, creativity-driven commitment to work, individualized reputation based on credit lines corresponding to the fulfilled projects, and talent understood as a metaskill, a potential for ceaselessly developing one's abilities, provided that the learning content of work remains high enough. Indeed, individualized trajectories inside the firm are heavily based on skill and behavioral versatility enhanced by diversified job assignments (Cappelli 1999; Appelbaum et al. 2000; DiMaggio 2001).

This means that the "professional" or "talent" type is no longer restricted to a highly specific form of expertise and to a highly specific form of training, control and exercise in some privileged occupations, but corresponds 1) to a new form of work organization that blurs the frontiers between firm and market and 2) inside the firm, to a new specification of the qualities of skilled work. One way to check whether that scenario has something realistic and credible to it is to look at fields or occupations where both numerical and functional flexibility prevail. I will consider two of them.

\subsection{Labor flexibility in the arts}

Artistic labor markets have evolved to approximate the spot-market model of textbook economics: Permanent employment relationships have largely vanished, and short-term hiring and self-employment strongly dominate. Thus, arts have often been mentioned as forerunners in experiencing the trend toward increasingly flexible high-skilled labor markets, where workers may be hired for only two or three hours, without any costly dismissal procedures. Flexibility is both intended to minimize fixed production costs and to enhance search for novelty and originality (Caves 2000; Hesmondhalgh and Baker 2010).

In relying on flexible ways of labor management, the expansion of the art and creative industries production has magnified the gap between labor demand and labor supply. Why? Research on the French performing arts labor market highlights 
Table $1 \quad$ Number and size of business entities in the audiovisual industry and the live performing arts sector in 1995, 2001 and 2008

\begin{tabular}{|c|c|c|c|c|c|c|}
\hline & \multicolumn{3}{|c|}{ Audiovisual } & \multicolumn{3}{|c|}{ Live Performing Arts } \\
\hline & 1995 & 2001 & 2008 & 1995 & 2001 & 2008 \\
\hline \multicolumn{7}{|l|}{ Type of business entity } \\
\hline Individual firms & 288 & 450 & 790 & 969 & 1422 & 910 \\
\hline Publicly-owned establishments & 4 & 4 & 3 & 14 & 13 & 19 \\
\hline Local authorities & 1 & 20 & 32 & 143 & 150 & 167 \\
\hline Associations & 941 & 1206 & 1504 & 7768 & 12770 & 16616 \\
\hline Private companies & 4545 & 6341 & 7861 & 1889 & 2922 & 3261 \\
\hline "Pseudo-siret"a & 295 & 416 & 118 & 9 & 10 & 1 \\
\hline Unknown & 6 & 3 & 0 & 11 & 28 & 0 \\
\hline \multicolumn{7}{|l|}{$\begin{array}{l}\text { Number of entities by } \\
\text { intermittent personnel size }\end{array}$} \\
\hline No salaried personnel ${ }^{b}$ & 1545 & 2374 & 1888 & 4909 & 7561 & 6327 \\
\hline 1 to 4 & 2813 & 3811 & 5499 & 4015 & 7070 & 10820 \\
\hline 5 à 9 & 865 & 1086 & 1258 & 956 & 1449 & 2052 \\
\hline 10 à 19 & 426 & 577 & 795 & 540 & 769 & 1080 \\
\hline 20 à 49 & 261 & 375 & 565 & 285 & 384 & 481 \\
\hline $50+$ & 170 & 217 & 303 & 98 & 82 & 214 \\
\hline Total & 6080 & 8440 & 10308 & 10803 & 17315 & 20974 \\
\hline
\end{tabular}

Source: Institut de la Statistique et des Etudes Economiques (INSEE) - Déclarations annuelles de données sociales a Establishments reporting wages paid to employees other than its own employees (temporary staff, trainees). ${ }^{b}$ Establishments that have employed at least one salaried artist or technical worker during the year, but reporting no employee at the relevant survey date (December $31^{\text {th) }}$.

these mechanics of the vertical disintegration in production and of the corresponding contingent work arrangements (Menger 2011). As shown in Table 1, the steady expansion of the performing arts sector since the 1980s has led to a rapid growth of the population of employers and to its increasing heterogeneity in terms of type of business entity and size of personnel employed on unfixed term and/or on fixed short term contracts.

What is the impact of the fact that labor demand is expressed mainly in terms of contingent work? An increase in the number of artists may be far from corresponding to a similar increase in the level of activity. The flexibility required by a system of project-based organization creates high frictional unemployment: At any given moment, the number of artists, and managerial and technical workers available must be significantly higher than the number of jobs allocated and distributed between projects under way, in order to ensure that the game of rapid staff re-allocation between projects with widely differing formats can progress unhindered. The re- 
Figure $1 \quad$ Trends in the performing arts labor market in France from 1986 to 2007 (index $100=1986$ )

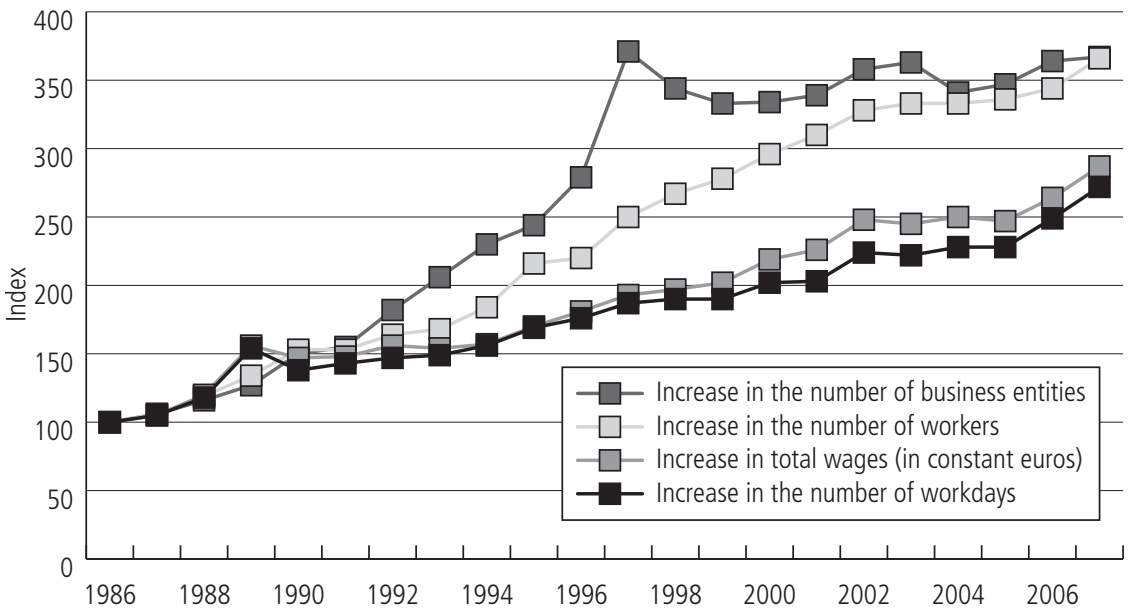

Source: Caisse des Congés Spectacle/Cespra.

sulting overall picture is a quite paradoxical one: Employment, underemployment and unemployment increase steadily and simultaneously.

In their extensive study on the vertical disintegration and flexible specialization trend in the Hollywood film industry, Christopherson and Storper (1989) showed that the aggregate quantity of work available increases far less rapidly than the pool of individuals employed intermittently, generating a growing competition and resulting in a decreasing average participation in production.

My research strongly supports Christopher and Storper's findings. Figure 1 shows how labor supply (i.e. the number of artists working) has evolved at rates of increase much higher than labor demand (i.e. the total amount of worked days declared and the total amount of wages). Significantly enough, the entrepreneurial boom has taken advantage of highly flexible schemes of employment, yet at the expense of the workers' average situation that worsened while the whole industry was rapidly expanding. The consequences of that unbalanced growth are highlighted in the Figures 2 and 3. The average amount of working time and earnings per intermittent worker decreased before plateauing when growth in the sector did slow down. Note that the job- and earning conditions for technical and managerial personnel are always better than what they are for artists.

A further exploration of the data (Debeauvais et al. 1997; Rannou 1997; Menger 2011) would detail how the artists' work situation differs from that of the 
Figure $2 \quad$ Trends in average annual working time 1986-2007 (index $100=1986$ )

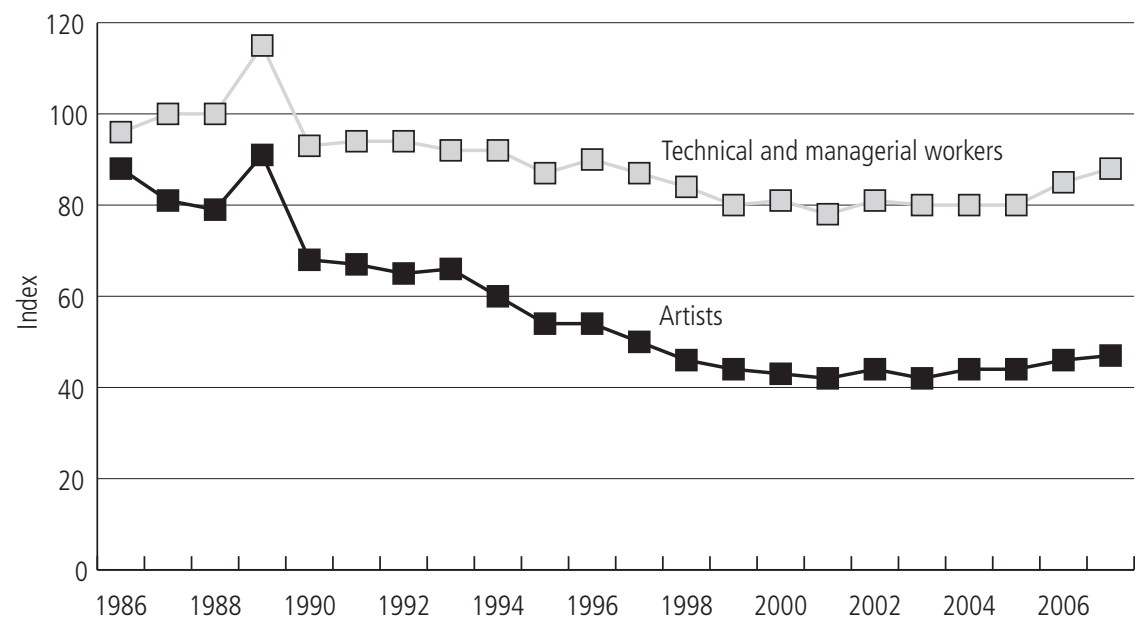

Source: Caisse des Congés Spectacle/Cespra.

Figure $3 \quad$ Trends in average annual earnings from intermittent work 1986-2007 (index 100 = 1986)

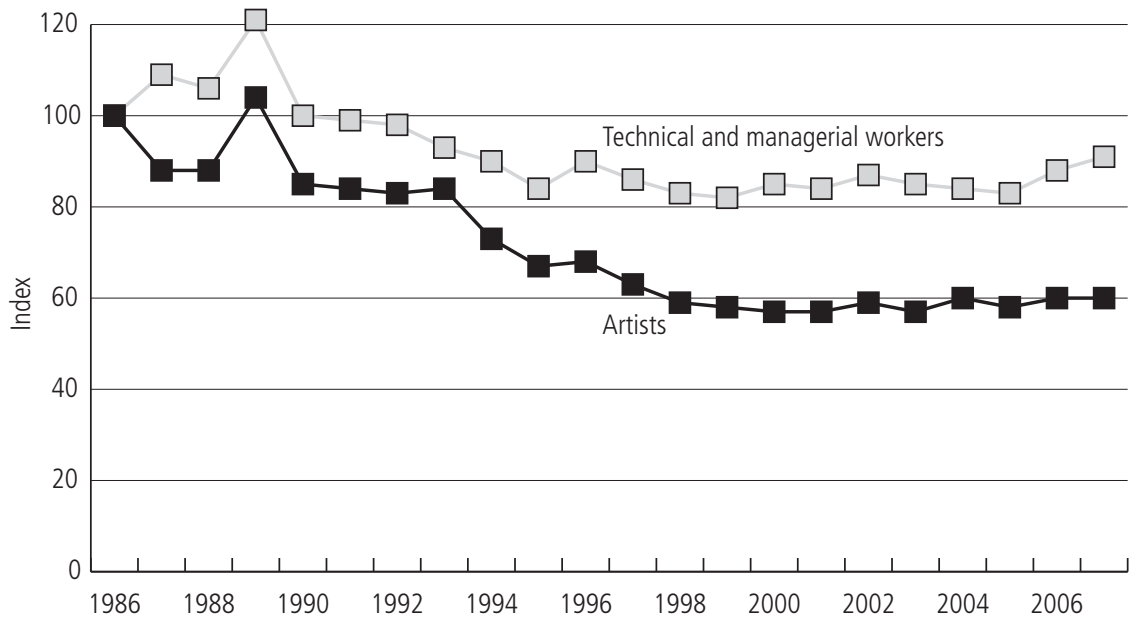

Source: Caisse des Congés Spectacle/Cespra. 
technical and managerial personnel. Artists receive shorter job assignments and experience tougher individual competition: Their skills are much harder to define and to check, competition through originality leads to speculation on talent, barriers to entry into the creative professions are lower and labor oversupply constitutes a structural component of the management of uncertainty in creative undertakings. The sectorial breakdown in Table 1 also reveals that the live performing arts sector, which consists mainly of non-profit, association-like, firms and on public funding from the State and the local authorities, is more vertically disintegrated than the for-profit, audiovisual and film industry.

\subsection{Labor market flexibility and risk management}

According to conventional economic theory, a labor contract is mutually advantageous when it provides both parts with insurance against misconduct and uncertain prospects. Several theoretical models have tried to capture the informational and temporal dimensions of the mutual insurance built-in property of the contractual relationship. Most of them show that only long-term contracts can meet such requirements to capture intertemporal aspects lacking in short-term relationships incentives to long-term productivity and insurance against wage fluctuations.

In the case of contingent work, the risk of unemployment is pervasive, and insurance devices through long-term contractual relationships are, by definition, missing. The typical worker will view the risk of unemployment as something that must be compensated for by a higher wage. Greater risks in earnings prospects offered by an occupation should also reduce the supply of labor. As already noted by Marshall (1947), some risk-prone workers who overestimate their chances of success may view it as an attractive gamble to enter an occupation where a few do very well while most do poorly, but the majority of workers will require a pay differential to compensate for uncertainty about lifetime earnings.

Compensation for uncertain labor prospects is in fact observed in the performing arts since intermittent artists and workers earn much higher hourly wages than those employed on a long-term basis. The wage premium is the price that employers must pay in order to draw on a reserve army of underemployed individuals whose availability has to be secured: a loss of flexibility in employment decisions would be costlier for firms.

Compensating wage differentials play their role both on the industry and the type of job level. In industries like television or motion pictures, where contracts are, on average, very short, workers are better paid than in the live performing arts where spells of intermittent work are longer. Figures 2 and 3 may also lead to speculate about the differences between technical and managerial workers and artists. Those differences have to be linked to composition effects. Technical and managerial workers are primarily employed in the motion picture and audiovisual industry. While getting higher hourly wages, these workers experience lower interindividual 
differences in earnings, since job competition is patterned by the true nature of the technical jobs that relies on skills and competencies. By contrast, artists' main sector of employment is in the live performing arts, where wages are lower on average, yet with a more skewed distribution than for technical workers. Indeed, praise and public recognition of creative talent lead to much greater earning inequalities, based on individual market value and not only on the amount of work supplied.

In any case, the compensating differential scheme operates only partially, since hourly wages are not higher for greatly underemployed workers than for their more successful fellows who are frequently rehired and can build continuity in their career. Individual differences in hiring probabilities are therefore not subject to compensation. That is simply to say that artists as well as technical workers in the performing arts do build their career on the basis of their reputation.

The normal pattern of activity for an artist with multiple employers can be described as successive alternations between periods of employment and periods, varying in length, of unemployment. In order for the workforce to remain available and thus to ensure the flexibility of artistic production, the cost of this availability must be shared. Part of it is covered by the employers who, as already mentioned, pay a higher hourly salary rate than in other sectors, controlling for skill level.

In many countries, access to unemployment insurance compensation is beyond the reach of freelancers. In France, since the 1960s, artistic and technical professionals of the performing arts, although acting as freelancers, have been equated by law with wage earners and are in consequence eligible to unemployment compensation. In addition, when the unemployment insurance expenses come under a selfadministered fund aimed at compensating every worker in the economy for his or her unemployment spells, a cross-subsidization between sectors facing contrasting evolutions may play the supporting role, provided that unbalance is temporary and solidarity can be reciprocated. The French unemployment insurance system put in place for artists and technical workers in the performing arts tells a different story, that of an increasingly flexible labor market prompted to internalize the benefits of its Unemployment Insurance (UI) system in order to sustain its persistently unbalanced growth.

\subsection{Lessons from the French specific unemployment insurance program for the performing arts and media industries}

A highly specific compensation scheme had been designed to fit the requirements of contractual flexibility in the performing arts, cinema and media industries. But it ran into financial issues because compensated unemployment grew more rapidly than paid work. From the 1980s onward, the publicly supported cultural sector boomed, and so did the audiovisual industry. Yet the rising labor demand started being allocated exclusively in the form of contingent jobs and short-term hiring that typically spread the available work among a growing number of agents. Thus 
the performing arts sector has expanded by having an increasing part of the income required to attract workers paid through unemployment insurance allowances. In aggregate, the amount of unemployment insurance benefits paid to those workers today in France represents more than two-thirds of their total amount of wages and fees.

A careful analysis of the behavior of both the workers and their employers shows how the unemployment risk has been increasingly endogenized by the employers, in order to keep their labor costs as variable as possible, while securing an optimally diverse pool of artists and craft workers in excess supply to lower the costs of innovation.

Menger and Gurgand's study (1996) of the specific UI program tailored for the arts and media industries ${ }^{7}$ has shown how it evolved during the cultural boom in France. Three changes occurred mainly over a period of about fifteen years, during which this sector experienced the steepest and most paradoxical rise in both employment and unemployment. First, among all the workers who met the eligibility criteria to get compensated by the UI program when unemployed, only a third applied in the early 1980s, but half of them did in the mid-1980s and 90\% in the early 1990s. Second, those figures might quite simply reveal a straightforward increase in unemployment risk as the intermittent working system expanded. Yet during the same period, underlying changes in behavior took place. Workers eligible to UI benefits experience three possible situations. They must accumulate enough working days within a certain period of time in order to qualify for compensation payments whenever they become unemployed. Thus, when qualified, they enter a compensation entitlement period (CEP), during which they can work on short-time contracts and nevertheless stay in the UI system: during these workdays, they get, of course, no UI benefits. Each of these working periods is taken into consideration, so that the worker, if she accumulates enough of these job records, is allowed to re-qualify for the next compensation entitlement period as soon as her current entitlement ends.

In 1980, only a third of the eligible intermittent workers actually did apply to get compensated and to alternate paid working time and unemployed compensated time. Two thirds of the labor force either worked enough to have no need of unemployment benefits or didn't learn how to smartly use their entitlement to compensation. In 1992, things had considerably changed. Not only, as mentioned, did almost all eligible workers resort to UI benefits within entitlement periods, but the average length of compensation time within a CEP rose sharply, from 247 days in 1980 to 294 days in 1992. Moreover, in 1980, only 36\% of all CEPs included some employment time, with $64 \%$ consisting of sheer compensated unemployment periods, like in usual unemployment situations. The former figure rose to $60 \%$ in 1985 and to $90 \%$ in 1992. Simply stated, inclusion of some working time into CEPs has generalized over the period and become the norm. This points to a significant

7 See appendix for a short description of the rules of that UI program. 
Figure $4 \quad$ Average length (in days) of employment contracts 1986-2007. Artists and technical workers in the audiovisual industry and in the live performing arts sector

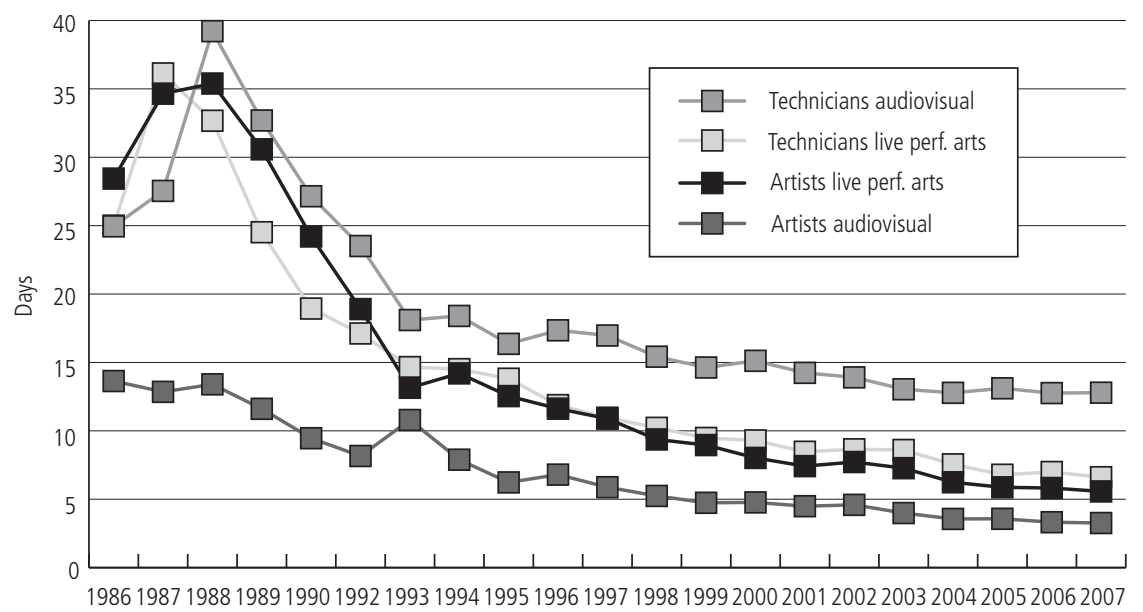

Source: Caisse des Congés Spectacle/Cespra.

change in behavior, whereby the flexibility of the system has been exploited more and more intensively, both by the employers and their intermittent employees, who learned how to cooperate in order to take advantage of such a flexicurity system ${ }^{8}$.

A compelling evidence of that process is provided in Figure 4. The average job duration has been decreasing almost constantly during the two booming decades, with sectorial and occupational differences conforming to what we know about the segmentation principles of this labor market. As already mentioned, technical and managerial workers, mainly employed in the audiovisual and film industry, fare much better on average than artists. In 2008, according to the author's calculations not reported here (see Menger 2011), average income of the former was $47 \%$ higher than that of the latter. Also, the share of compensation resources drawn from UI correlates negatively with the annual total income: in 2016, technical workers receive on average $37 \%$ of their income from UI allowances, to be compared with the $56 \%$ compensation share derived by artists from transfer income (Unédic 2016).

An additional way to measure this phenomenon is to look at the number of employment periods within CEPs. These rose from 4.4 to 15.5, indicating an increased fragmentation of CEP time. Measuring the length of time between two consecutive CEPs of the same individual provides a different assessment of this pattern. In the early 1980s, a typical career consisted of CEPs with no interruption for employment, separated by nearly a year. In the late 1980s, the picture was that of fragmented time, with intricate working and compensation periods. 
Table 2

Total wages and total UI compensation of intermittent workers (€ million constant 2007)

1992199319941995199619971998199920002001200220032004200520062007

Total wages(1) $10251017103211171192 \quad 127013011331 \quad 14441485163216121645162417421893$

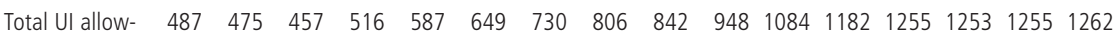
ances (2)

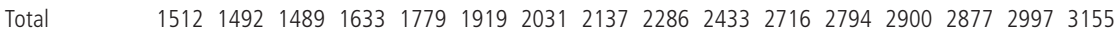

$\begin{array}{lllllllllllllllll}\text { Ratio } 2 / 1(\%) & 48 & 47 & 44 & 46 & 49 & 51 & 56 & 60 & 58 & 64 & 66 & 73 & 77 & 77 & 72 & 67\end{array}$

Source: Caisse des Congés Spectacle/Cespra and Unemployment Insurance Fund.

Having smaller spells of employment located in compensated entitlement periods helped employers to provide their contingent workers with shelters to buffer the underemployment risk, without incurring the costs of securing long-term career prospects. As shown in Table 2, the unbalanced expansion of the sector can be summarized in a paradoxical trend: While labor demand increased, the total amount UI benefit expenses increased as well and even faster than the total amount of wages. As growth in the creative industries sector was based on rising contingent work, its insurance component increasingly leaned on transfer resources. Since the late 2000s, the wage/allowances ratio has fluctuated only in narrow, suggesting that the central tendency is firm enough to be understood as the result of a strategic equilibrium (Menger 2011).

In investigating a flexible work scheme such as the one presented herein, I have brought to the forefront the simultaneous increase in employment and unemployment. Furthermore, I tried to explain how it is grounded in the flexible work system and its unbalanced growth of labor supply and demand. Thus, the pervading risk of constrained underemployment (non-voluntary part-time work, intermittent work, fewer hours of work) in highly flexible employment and contract work settings has to be balanced against the defining characteristics which may explain its attractiveness in highly skilled occupations, such as autonomy, responsibility, selfcontrol in teamwork, extended range of abilities enhancing the sense of initiative, creativity-driven commitment to work, individualized reputation based on track records and team project organization of work. This is why, when large parts of the business risk is transferred down to the workforce in flexible and disintegrated organizational settings, workers must learn to manage the risks of their trade in a very entrepreneurial way, through multiple jobholding, occupational role versatility, portfolio diversification of employment ties, and transfer incomes from public support, social insurance and social security programs. 


\section{Bridging the gap between employment and self-employment: contract work} and the umbrella company option in France

Salaried employment has been undergoing an increasing diversification in the way it is made accessible to workers (Cohany 1998; Dupuy and Larré 1998; Morin et al. 1999; Kalleberg 2000; Gazier et al. 2016). One major example was provided in France by independent contract consulting through umbrella companies (or portage salarial, as it is known in France). It has become a way for self-employed professionals to offer their services and still benefit from the welfare protection provided to salaried workers, at least partly (Menger et al. 2007). Emerging in the 1990s, it has expanded since, initially at the margins of the labor law rules, then was legalized in 2008, after numerous rounds of expertise and controversial social negotiations (Casaux-Labrunée 2007). Finally, its legal status was confirmed in 2015. This contract work arrangement was initially suspected of dismanteling the salaried employment legislation and its legal and social protections: Outsourcing practices could expand and yet salaried workers now turned into freelancers could be offered an attractive level of social protection. It was indeed suspected to implement a flexicurity scheme that would allow umbrella companies and the employers buying the independent contractors' services to take undue advantage of the UI safety net designed to protect regular salaried workers. If used strategically, as it is the case of intermittent workers, it would make both uncertain hiring prospects and the cycling behavior between working and non-working time far more attractive. On the other hand, independent contract consulting has been promoted by umbrella companies as a way to boost self-employment and entrepreneurship, especially by helping dismissed professional and managerial workers switch to freelancing, and by subsidizing their learning process.

The research I conducted took place at a time when the legal and political controversy over the legalization of this hybrid arrangement between employment and self-employment peaked, in the mid-2000s. This explains why the research protocol is quite unique. I was first able to gather data on work and personal income from the umbrella companies and then to match them with data on unemployment compensation provided by the UI organization ${ }^{9}$. Independent contract consulting through umbrella companies takes the form of a three-way contractual relationship. The independent consultant finds contract jobs for one or several client companies; the umbrella company enters into a membership agreement and concludes both a contract for services with the consultant and a business contract with the client company. The umbrella company issues an invoice for the contract performed by

9 As data relating to contract work does not fall into a specific category in the official statistical sources on employment and the labor market and has gotten a specific identifier in the employment records of the UI agency only in 2015, a survey of that expanding contractual arrangement has to start afresh, especially if it focuses on exploring the interplay between freelancing development and the use of UI as a safety net. 
the consultant, collects the payment, and pays the contractor his remuneration in the form of a salary, less social insurance contributions and a commission covering the umbrella company's financial and administrative management fees relative to the contract performed.

Independent contractors often alternate (by choice or necessity) between periods of working under contract and periods without contract. During the latter, contractors can claim unemployment benefits. This triangular scheme is clearly tailored to meet the needs of firms who are looking for consultant services that are cheaper or much more limited in scope and time than those provided by consulting firms. It also offers the latter the possibility of subcontracting consultant work to self-employed professionals for highly specific assignments or for overhead costs savings' sake. Thus freelancing work in consulting services illustrates one path to flexibility, yet with one additional characteristic I strongly insist on here: to provide risk-taking workers with some protection against underemployment.

\subsection{The umbrella company anchor}

One of the most spectacular properties of the umbrella company vehicle is the drastic reduction in recruiting and labor management costs, since the company is the passive recipient of job offers brought in by the consultants, who thus set in motion the three-way relationship. The dematerialisation of the physical and managementrelated environment, which exists as a result of portage, is no less striking: The fact that consultants have the ability to manage their own personal work data via the Internet is a clear sign of autonomy. The doctrine is simple: Umbrella companies erect no barriers to entry into the independent contract consulting arena. It is up to consultants to weigh the costs and advantages of each available form of employment (or reintegration into the workforce, in the case of dismissal or unemployment), and choose the most efficient solution. This process, defined by the self-selection of those applying for the status of self-employed professional, unavoidably leads to very different career paths amongst consultants, as the latter often have no other choice but to evaluate the suitability of the independent contract consulting vehicle as they go along; in order to enhance the sustainability and profitability of their career choice, they must weigh the chances of every significant sequence of contract over the long term, and also assess how to manage the risks that go hand in hand with their self-employed status.

The mechanism that governs the matching of consultants with umbrella companies can be identified by examining consultants' individual paths, as some manage to consolidate their careers while others withdraw from this arena. Based on individual employment data, I have observed close to 5000 individual situations over a period of three years; most notably, we looked at 2300 contract consultants who were in gainful employment in 2003, and compared this data with figures for the two years that followed, to determine whether they maintained this status or 
had dropped out ${ }^{10}$. The conclusions of this observation are easily summarised. One third of those who started out as contract consultants vanished from the database the following year. The rate of attrition was the same for those who stayed on another year: over three years, the initial population decreased by more than half. Correspondingly, the annual rate of turnover of declared contract consultants was very high ${ }^{11}$. Intermittent portage, whereby professionals worked as contract consultants on and off over the three years, was very marginal, because those who drop out of contract work for over one year appear to stand little chance of returning. This is somewhat of a paradox, as one of the most salient characteristics of contract- and project-based employment is that it introduces a permanent risk of high discontinuity in the personal work system. Such discontinuity is elastic only up to a point: Beyond several months' inactivity, the odds of staying aboard such employment vehicle decrease considerably. In other words, discontinuous contract-based work presupposes that consultants are always present on the market, efficiently seeking jobs and obtaining a steady flow of contracts upon which they will be able to build and sustain a durable reputation for employability.

It is possible to measure a number of characteristics that enhance the employability of professionals who settle durably in the independent contract consulting system (Table 3).

The conclusion is suggestive: The consultants that stayed on the umbrella company's payroll one or two years after 2003 were more active and better paid compared to the first year. Median figures suggest that the advantage was already quite sizeable for those who were with the company for no more than two years, but it was significantly greater for those who stayed the longest. Contract consultants who stayed active over three years had a more consistent profile, since their

10 Each contractor observed between 2003 and 2005 could fit one of the 7 following profiles, the proportion of which within the overall sample is given in between brackets: 1) present for three years on the umbrella company's paylist $(22 \%) ; 2)$ present the first two years, then absent $(9.8 \%)$; 3 ) present the first year, then absent for two years thereafter $(13 \%) ; 4)$ present the first and third years, but absent the second year $(1.3 \%) ; 5)$ absent the first year but present the two following years $(16.7 \%)$; 6) absent the first two years, then present the third year $(28.4 \%)$; 7) absent the first and third years, but present the second year (8.7\%). Our longitudinal analysis concentrates on profiles 1 to 4, as our aim is to assess the "staying ability" of individuals who started out in business at the same time. One of the limits of this analysis stems from what statisticians call data censorship: we know nothing of the past of those that were on the paylists in 2003, nor of the future of those that were still present or just came on board in 2005. This twofold censorship does not preclude a descriptive analysis, based on the assumption that cohorts observed every year correspond to a rather stable mix of profiles. The other limit is due to the lack of information on possible transfers of contractors from one umbrella company to another - having dropped out of a sample does not imply ipso facto that a contractor is no longer working through an umbrella company. However, the statistical data related to the profile of those who dropped out of the sample as well as the personal accounts gathered in the course of the survey provide a likely description of the mechanism leading to withdrawal from this employment vehicle.

11 The global turnover index, computed as the ratio: (newcomers + leavers) / ( $2 \mathrm{x}$ contractors present), was $38 \%$ - this is a significant number when judged against the mobility of staff in companies with a regular salaried workforce. 
Table 3 Contract consultants in 2003 according to their future

\begin{tabular}{l|r|rr|rr|rr}
\hline Profiles $^{\text {a }}$ & $\begin{array}{r}\text { Number of } \\
\text { consultants }\end{array}$ & \multicolumn{2}{|c|}{ Gross salary (Euros) } & \multicolumn{2}{c|}{$\begin{array}{c}\text { Number of paid } \\
\text { working hours }\end{array}$} & \multicolumn{2}{|c}{ Hourly rates } \\
& & Average & Median & Average & Median & Average & Median \\
\hline 100 & 652 & 5148 & 2270 & 160 & 70 & 43 & 28 \\
101 & 64 & 3860 & 2143 & 143 & 70 & 48 & 30 \\
110 & 490 & 9240 & 3461 & 303 & 147 & 31 & 23 \\
111 & 1098 & 10797 & 5412 & 365 & 219 & 33 & 25 \\
\hline
\end{tabular}

a How to read profiles: a 1 indicates a professional was "on the payroll of the company during the year", while a zero indicates "not on the payroll that year". Thus 100 means the consultant worked only in 2003; conversely, 111 denotes continuous presence on the payroll for three years; 101 suggests a professional dropped out in 2004, etc.

individual situations were less disparate (as measured by the gap between average and median). The "survivors" showed a greater degree of aptitude for self-employed work, individual productivity and exposure to market demand. They plainly represent a core group within the contract consulting market that built up as selection occurs on the basis of the probability of surviving in this field. Judging from hourly rates, it is clear that the greater the volume of work, the greater the chances of staying on in this form of employment, and the greater the chances of earning more. A self-reinforcing causal relationship develops when contracts are obtained through an umbrella company: As professionals get more and more contracts, they learn to fully reap the advantages of this work-engineering solution and to efficiently tap the resources and the intermediation logistics offered by the umbrella company.

\subsection{Contract work through umbrella companies as a way of securing unemployment insurance}

An increasing variety of intermediaries aim to organise contract work: temporary employment agencies, staffing firms, job-sharing agencies, pooled "inter-contract marketplaces," or umbrella companies, where consultants can find jobs to minimise intercalary periods without work, etc.; they all offer optimized social welfare and unemployment insurance solutions for people in atypical employment.

One of the arguments in favor of the intermediation industry is that umbrella companies help unemployed people to reintegrate into the job market. This claim has gained in legitimacy in a context where unemployment is high and numerous mechanisms are at play, which drive specific categories of workers out of the labor market, most particularly those over fifty and, more disturbingly, qualified or highly qualified individuals. The aim of the support given by umbrella companies 
to contractors whose activity is fragmented is also to protect them with the tightest possible safety net.

Were this atypical form of employment not linked with some form of insurance against the recurrent alternation between in-work and out-of-work periods, contract work via an umbrella company would offer no decisive compensation for the risk involved in going self-employed, would lose part of its appeal, and could no longer claim to help people get back to work.

What is the situation of contract consultants with regard to unemployment insurance? From data supplied by the Groupement des Assedic de la Région Parisienne (GARP $)^{12}$, we know a few things about the work and unemployment experience of those who have worked long enough to be entitled to compensation, whether or not through an umbrella company. Eighty per cent of contracts for services followed by phases of compensated unemployment are fixed-term contracts. Considering the variety of contracts mentioned by umbrella companies when presenting their range of contract options (part-time or full-time open-ended contracts, intermittent work contracts, flexible part-time contracts, and full- or part-time fixed-term contracts), the overwhelming predominance of fixed-term contracts seems to indicate, perhaps predictably, that this is a type of casual flexible employment which can be made more secure through unemployment insurance.

Another essential variable is the way contracts fit into a sequence of compensation, according to the principle that it is possible to receive unemployment benefits while engaged in reduced employment. The umbrella company vehicle is a clear illustration of this trend. We analysed a sample of 639 contracts of variable length between umbrella companies and contractors, where the latter then moved on to being unemployed and claiming the relevant benefits. We found that $56 \%$ of those contracts were located in a "reduced activity" scheme that has allowed workers to combine wages and UI benefits. On average, the alternation of short-term employment and compensated unemployment lasts 560 days, and reduced employment stands at roughly 10 hours per week (figures averaged out over each sample period). For individuals who accrue enough hours of work to claim unemployment benefits, the umbrella company vehicle does indeed achieve the desired objective, in that it mitigates the discontinuity of contract work.

Anytime work and unemployment status can be combined, unemployment benefits must constitute a certain income, which supplements the discontinuous and uncertain earnings derived from reduced activity. A number of umbrella companies explicitly state this argument on their websites, explain and even help to precisely calculate how to make the most effective use of the legislation that applies to a reduced activity, in order to mitigate the troughs between contracts. Our analysis of

12 GARP provided us with anonymized data for a sample of contractors who had contracts with a set of Paris-based umbrella companies and experienced periods of compensated unemployment. We analysed data covering approximately ten years, but have limited our observations to the years spanning 2000 to 2005 . See also note 6 . 
contracts conducted through umbrella companies and declared under the reduced activity scheme shows (see Table 4 below) that independent contractors over the age of 50, who make up close to one third of our sample of those who have been on unemployment at any time, tend to combine unemployment and reduced activity the longest, in accordance with the provisions of the law (701 days, compared to 492 days for those under 50). As shown in Table 4, the financial impact of this combination is as follows: reduced activity can, on average, almost double the earnings of a person working through an umbrella company while on unemployment benefits; the probability of doubling one's income increases with time up to a maximum of two years, after which the intensity of reduced activity declines. The average value of income from compensation and reduced employment for professionals over the age of 50, which is close to two and a half times higher than for those under 50, is calculated on the basis of length of unemployment and invoiced amounts with respect to contracts falling within the scope of reduced activity. Indeed this is where the profile of the manager over 50 emerges clearly. Similarly, our data corroborate the gender bias observed on the independent contract consulting market: While women obtain contracts in more poorly remunerated specialities, leading to correspondingly lower benefits, there is also a greater supply of contracts directed at a mostly female workforce, which enables women contractors to significantly increase the amount of work carried out under the reduced activity system, which again enhances the value of the scheme as a financial incentive.

The situation of contract consultants with respect to unemployment insurance is no different from what can be observed on the labor market in general. Over the past fifteen years, reduced activity has developed considerably amongst workers receiving unemployment payments. In 2005, one third of unemployed individuals engaged in reduced work, i. e. eleven times more than in 1991; just over half of these 837000 claimants carrying out reduced activities combined work-related earnings with unemployment benefits. In 2013, more than a million jobseekers undertook a reduced activity every month, i. e. almost one out of every two benefits recipients (Blouard et al. 2013). Of course, that growing population is very heterogeneous. Our contractors are distinctively highly skilled, and a significant fraction of them are committed to an independent activity on a long-term basis, in sharp contrast with the mass of unemployed workers that experience the fragmentation of low-skilled labor demand in ever shorter fixed-term contracts and use reduced activity to make it up and maintain their employability. Hence the simple question which arises from our analysis of contracting consultant and umbrella company data: Can the coverage of risk inherent to contract work be considered sustainable if the unemployment insurance mechanism is used on a long-term basis and to the full for its strategic qualities, in that it helps to offset systematic discontinuity in employment, and if the risk of shortage of work is no longer exogenous, i.e. beyond the control of stakeholders, but transferred away from the employers or the clients who pay for 
Table $4 \quad$ Comparison of earnings from unemployment benefits and reduced activity for contractors working through umbrella companies

\begin{tabular}{|c|c|c|c|c|c|}
\hline & $\begin{array}{r}\text { Reduced } \\
\text { activity } \\
\text { contracts }\end{array}$ & $\begin{array}{r}\text { Average } \\
\text { unemployment } \\
\text { benefits }^{\mathrm{a}}\end{array}$ & $\begin{array}{r}\text { Average } \\
\text { earnings } \\
\text { from reduced } \\
\text { activity }^{a}\end{array}$ & $\begin{array}{r}\text { Ratio: } \\
\text { earnings } \\
\text { from reduced } \\
\text { activity/ } \\
\text { unemployment } \\
\text { benefits }\end{array}$ & $\begin{array}{r}\text { Cases where } \\
\text { income from } \\
\text { benefits }>\text { earn- } \\
\text { ings from } \\
\text { reduced activity }\end{array}$ \\
\hline All individuals & 361 & 25323 & 23679 & 0.94 & $0.56 \%$ \\
\hline Men & 176 & 33744 & 26156 & 0.78 & $0.60 \%$ \\
\hline Women & 185 & 17312 & 21323 & 1.23 & $0.52 \%$ \\
\hline Under 50 & 247 & 16834 & 16938 & 1.01 & $0.53 \%$ \\
\hline 50 or older & 114 & 43717 & 38284 & 0.88 & $0.61 \%$ \\
\hline $\begin{array}{l}\text { Benefit Duration: } \\
-265 \text { days }\end{array}$ & 92 & 8675 & 6322 & 0.73 & $0.65 \%$ \\
\hline $\begin{array}{l}\text { Benefit Duration: } \\
265-427 \text { days }\end{array}$ & 90 & 13677 & 13367 & 0.98 & $0.50 \%$ \\
\hline $\begin{array}{l}\text { Benefit Duration: } \\
427-745 \text { days }\end{array}$ & 90 & 24191 & 25369 & 1.05 & $0.47 \%$ \\
\hline $\begin{array}{l}\text { Benefit Duration: } \\
745 \text { + days }\end{array}$ & 89 & 55455 & 50340 & 0.91 & $0.62 \%$ \\
\hline
\end{tabular}

Source: GARP.

Scope: sample of consultants holding contracts with umbrella companies who received unemployment payments and engaged in reduced-activity work.

2005 deflated Euros.

a service over to the workers, the onus being on the intermediaries to offer tailormade risk-reduction solutions? This clearly may cause the traditional unemployment insurance, which aims to cover unemployment risk, to evolve, as the system is.

\subsection{The employer, the contingent worker and the insurer - a strategic game}

An intriguing issue is the role played by the unemployment insurance system when employment and unemployment trends correlate positively. For those consultants, freelancers, artists and creative workers who are eligible for unemployment benefits, as in France, the resulting combination of security and autonomy at work performs two different functions:

providing earnings replacements which reduce the compensating pay differential associated with the risk of unemployment and the uncertainty about lifetime earnings - in fact the position on the contingent labor market may be optimized, so that each individual permanently combines fees and unemployment benefits; 
> subsidizing non-working time which can be used as training time for a future demanding job, as a searching period for new jobs, as leisure time or possibly as a way to manage the multiple jobholding portfolio that may combine salaried jobs and self-employed positions.

Note that in the first function, unemployment is mainly seen as a constraint on individual behavior via a labor-demand explanation, whereas in the second function, that refers to a labor supply explanation, unemployment can be interpreted as the outcome of a worker's choice with regard to job search. Yet ambiguity may arise from the way uncertainty about job and earnings prospects is itself interpreted. As observed by Drèze $(1987,349)$, "in the case of the self-employed the distinction between endogenous and exogenous economic uncertainties is not always clear-cut." Consequently, insurance against career failures does raise questions.

As Topel and Welch $(1980,354)$ point out in their survey on unemployment insurance issues,

to the extent that workers take future unemployment benefits into account when evaluating a job offer, this effect must be ambiguous. While workers will certainly be more selective with respect to job offers if benefits are increased, the value of any particular job must be comprised of both income from working and benefit income from contingent unemployment. The increase in benefits will allow firms to offer the same value of an employment contract with a lower wage.

Accordingly, substantial moral hazard becomes pervasive if the insurer (the UI fund) is unable to differentiate unpredictable exogenous constraints on the hours intermittent workers are able to sell in the market from the worker's choice, with regard to job search or allocation of non-market time.

As for the cases studied in this paper, Topel and Welch's reasoning should include the already mentioned interaction between the implementation and growing intervention of the specific unemployment insurance, on the one hand, and the fragmentation and outsourcing of allocated work, on the other hand. It then appears that the "ambiguous effects" are much less so on the employers' side. As a matter of fact, employers are able to exploit asymmetrical information about their work and job allocation agenda in order to include entitlement to unemployment insurance benefits in their wage bargaining with their contingent employees. In so doing, employers and firms can achieve two different goals. First, they draw at will from a considerable reserve army of underemployed workers to sort out the most talented and to build well-matched teams. Turning their labor costs mainly into variable ones, by tailoring them to meet the needs of a project-based organization of work, they actually do lower their overall labor costs. Second, they offer hourly wages that are far higher than in other industries. That differential can certainly be interpreted as a risk premium compensating for that high-skilled contingent work- 
force in exchange for persistent uncertain job prospects. But wage has become on average a decreasing part of the overall income of the intermittent workforce, with UI allowances becoming the major and the most certain part of one's earnings, as provided eligibility is secured.

To meet those two goals simultaneously, employers took advantage of the overall UI rules. The specific intermittent UI scheme is part of the general UI system designed to insure the whole workforce in the private economy. Its rules allow for cross-subsidization: The benefit payments of some industries or some specific regimes are subsidized at the expense of others, provided that the aggregate UI system does balance itself out, that is as long as cross-subsidization occurs to compensate for sectorial and cyclical ups and downs in the economy. Yet that specific regime has steadily generated a deficit: Workers' and employers' contributions to that specific regime have never covered more than a quarter of its expenses since the mid-eighties. Strikingly enough, the workforce of those industries and their employers cooperate strategically against each major reform meant to re-balance the books or at least to slow down the deficit trend, not to mention sheer suppression plans (Menger 2011). Attempts to fix the deficit by significantly raising the employers and employees' contributions and/or by cutting down allowances have thus repeatedly failed. They have each time been faced with vehement protests and successful strikes by the major union of that sector (Sinigaglia 2012; Grégoire 2013; Langeard 2013). What's more, the political authorities, using the UI specific fund as a deliberate means of public policy in support of the arts, have interfered in the social negotiations to defer each major reform plan, to minimize its scope or to backtrack on its implementation.

An increasing variety of job market intermediaries aim to organise contract work: temporary employment agencies, job-sharing agencies, pooled "inter-contract marketplaces," where consultants can find jobs to minimise interstitial periods without work, etc. They all strive to offer optimised social welfare and unemployment insurance solutions for people in atypical employment. Contracting through the umbrella company vehicle has been claimed to be part of the new back-to-work schemes for redundant employees, or for seniors forced out of the labor market early on. This claim has gained in legitimacy in a context where unemployment is high and numerous mechanisms are at play which drive out of the labor market specific categories of workers, most particularly those over fifty and, more disturbing, skilled or highly skilled individuals. The aim of the support provided by umbrella companies to contractors was also to protect them with the tightest possible safety net against recurrent, predictable or unpredictable, periods of intermittent unemployment. I have indeed shown that independent contracting has developed and increasingly leaned on the social protection and UI financing to insulate independent contractors from the business risk of freelancing.

In so doing, umbrella companies have claimed the right to draw on the UI fund and its multi-sectorial solidarity. The triangular strategic interaction I have 
pictured above - between employers, workers (and their umbrella firms) and the UI agency - takes on almost the same characteristics as in the intermittent workers case, with public authorities regarding it as an additional piece of their active labor market policy. At the end of a lengthy legal battle, the hybrid salaried freelancing and its umbrella companies were granted full legal recognition in 2015, including the access to unemployment benefits that was crucial for its development.

As shown above, once employers or umbrella firms allow or even induce their contingent employees to take full strategic advantage of unemployment compensation, UI expenses grow faster than contributions, due to substantial moral hazard. As it is well known, in presence of asymmetrical information with moral hazard, implementation of an experience rating formula is the best-known way to make employers responsible for the impact of their hiring decisions on the fund's finances (Atkinson and Micklewright 1991; Chiappori 1996; Blanchard and Tirole 2003; Cahuc and Kramarz 2004). Under that formula an employer's unemployment insurance tax rate depends upon the amount of compensated unemployment his allocation of contingent jobs generates yearly.

A fine-grained experience rating scheme should set upper and lower bounds on payroll taxes, which would also vary with the characteristics of the business, e. g. with the firm size, sectorial differences in constrained (seasonal) variability of activity, access to alternative employment schemes, type of business entity (Menger 2004). Under even imperfect experience rating, a significant rise of the payroll tax rate intended to provide a more efficient funding of the unemployment insurance scheme might be mitigated in the non-profit cultural sector to fit in with public cultural policy aims. This can take the form of an arrangement that passes a fraction of the extra costs incurred by the agent under the experience rating formula onto a subsidization scheme set up by the principal, yet based on extensive empirical evidence to remedy the pervasive asymmetry of information the current system is plagued with. In so doing, the principal might take into account the functional need of flexibility in the creative industries business, while inducing the agents to factor in the entire costs (paid wages and unemployment benefits generated) of their flexible hiring practices.

\section{Conclusion}

Work organization and employment conditions studied herein differ from the usual picture of strictly separated individual situations and positions that correspond to salaried employment within a firm, where shifting situations from one individual state (activity) to another (unemployment) are well defined and combinations of situations are marginal. 
According to textbook models of economic theory (Borjas 2005; Boeri and Van Ours 2008), the labor market would be a perfectly competitive and efficient one if work were a homogeneous and easily measurable quantity, if information on both sides of the market were complete, if factors of production were mobile, if people could cycle between work and unemployment as often and as easily as needed, if skills were transferable assets. If so, the labor market would be truly flexible. Social insurance devices would provide workers with sufficient protection against precariousness, by easing the complementarity between work and out-ofwork individual situations (Schmid 2015). Could it then be that the firm amounts to an essentially imperfect reality and could be brought down to a mere nexus of contracts, with the frontier between market and organization eventually blurred? Neo-institutional economics (Williamson 1986) has shown that the firm can, better than the idealized competitive market, take charge of the unavoidable imperfections of the work organization. Yet the distinction between market and firm is evolving: organizational efficiency, optimal size of the firm, new forms of coordination among units inside the firm, and an increasingly large range of means designed to raise the level of flexibility in the work organization tell us that the competitive market is to a degree brought inside the firm.

This issue may take on renewed importance since we have entered the so-called knowledge economy and platform economy, where matching devices of high-skilled labor supply and demand take full advantage of free agency. Flexibility and creativitydriven rise of labor productivity are then advertised as more tightly linked than ever. Yet when flexibility leans on fixed-term or independent contracting, the way workers get insured against recurrent unemployment spells and hiring shortage is of paramount importance. I have first shown that the various meanings and values of flexibility need to be carefully unravelled. Then, in order to compare the two species of flexible work arrangements investigated, I have deliberately focused on the triangular relationship employer-employee-insurer, which is at the heart of a flexicurity scheme. The ambivalent effects of its implementation and internalization have surfaced. Yet, I left aside some major properties of a reputation-based allocation of work in highly flexible labor markets. Two of them are worth mentioning at this point, to delineate perspectives of further investigation.

First, self-employed artists' careers display most of the attributes of the entrepreneurial career form: the capacity to create valued output through the production of works, performances and services for sale; the motivation for deep commitment and high productivity associated with their occupational independence (deriving from the capacity to control their own work, a strong sense of personal achievement through the production of tangible outputs and the ability to set their own pace). ${ }^{13}$ To put it more precisely, being neither a stage process nor a simple bargaining pro-

13 On the value given to autonomy at work, see Jencks and Rainwater 1988; Hundley 2001; Kunda et al. 2002; Benz and Frey 2006; Eurofound 2012. 
cess, career trajectories under a self-employed or a contingent work status combine traits from professional as well as from entrepreneurial careers as defined by Kanter (1986). High-skilled freelancers rely on skills as well as on opportunities to take on evermore challenging assignments that bring them greater knowledge and more rewards; they have an external market value based on reputation; they exhibit multiple loyalty; and they may manage their working life much as property owners do when spreading their risks.

Second, such trajectories also entail a higher degree of risk-taking, as shown by the highly skewed distribution and high variability of earnings (Alper and Wassall 2006; Menger et al. 2007). Thus, self-employment may bring with it an illusory independence and autonomy (Freidson 1986) or a highly ambivalent and "very complicated version" of freedom (Hesmondhalgh and Baker 2010). Indeed, considerable inequalities in amounts of work and earnings among creative workers and independent contractors are observed. Allocation of work under a contingent employment scheme should not cause the kind of permanent excess supply of labor which employers and customers benefit from, were it not for the rationales of occupational commitment to attractive non-routine, expressive work. Inequalities of course also trace back to the way a flexible labor market operates. Employers as well as labor market intermediaries and talent brokers use individual work credits and reputations as screening devices and signals for further employability. Allocation of piecemeal work certainly favors loose employment relationships, but also labor force segmentation, since filtering mechanisms and selective matching processes based on recurrent hiring ties generate transactional stability as well as contingent labor force segmentation (Faulkner and Anderson 1987). As cumulative productivity profiles greatly differ, distinct matching proclivities segment the labor market; team matching is neatly stratified in equivalent classes of market agents (Accominotti 2008).

The two types of flexible employment schemes studied herein usually fall into one larger category, that of alternative work arrangements. There is a growing body of research exploring those non-standard forms of work and the related online and offline intermediation and brokerage technologies (Autor 2001, 2009; Dokko et al. 2015). Most recent studies now strive to both survey the statistical incidence of those arrangements in the economy and define new legal statuses to extend some of the benefits of employees' social protection to contingent and to independent contractors as well (Harris and Krueger 2015). As a contribution to that literature, my paper provides unique - yet limited empirical material that calls for further, longitudinal, investigation based on systematic matching of employment and unemployment insurance individual data. 


\section{$5 \quad$ References}

Accominotti, Fabien. 2008. Marché et hiérarchie. La structure sociale des décisions de production dans un marché culturel. Histoire \& Mesure 23(2): 177-218.

Aghion, Philippe and Peter Howitt. 2009. The Economics of Growth. Cambridge: MIT Press.

Alper Neil and Greg Wassall. 2006. Artists' Careers and their Labor Markets. Pp. 813-864, in Victor Ginsburgh and David Throsby (eds). Handbook of the Economics of Art and Culture. Volume 1. Amsterdam: Elsevier.

Appelbaum, Eileen, Thomas Bailey, Peter Berg, and Arne Kalleberg. 2000. Manufacturing Advantage. Why High-Performance Work Systems Pay Off. Ithaca: ILR and Cornell University Press.

Atkinson, Anthony B. and John Micklewright. 1991. Unemployment Compensation and Labor Market Transitions: a Critical Review. Journal of Economic Literature 29(4): 1679-1727.

Autor, David. 2001. Wiring the Labor Market. Journal of Economic Perspectives 15(1): 25-40.

Autor, David (ed.). 2009. Studies of Labor Market Intermediation. Chicago: University of Chicago Press.

Bakhshi, Hasan, Eric McVittie, and James Simmie. 2008. Creating Innovation: Do the Creative Industries Support Innovation in the Wider Economy? London: NESTA.

Banks, Mark and David Hesmondhalgh. 2009. Looking for Work in Creative Industries Policy. International Journal of Cultural Policy 15(4): 415-430.

Benz, Mathias and Bruno Frey. 2006. Being Independent is a Great Thing: Subjective Evaluations of Self-Employment and Hierarchy. Economica 75(298): 362-383.

Baron, James and David Kreps. 1999. Strategic Human Resources. New York: John Wiley and Sons.

Bennett, Tony and David Carter (eds.). 2001. Culture in Australia: Policies, Publics and Programs. Cambridge: Cambridge University Press.

Bilton, Chris. 2006. Management and Creativity. Oxford: Blackwell.

Blanchard Olivier and Jean Tirole. 2003. Protection de l'emploi et procédures de licenciement. Paris: La Documentation française.

Blouard, Jean-Paul, Baptiste Costanzo, and Marie-Hélène Muhl. 2013. La croissance continue de l'activité réduite recouvre des réalités et des publics différents. Paris: Unédic.

Boeri, Tito and Jan van Ours. 2008. The Economics of Imperfect Labor Markets. Princeton: Princeton University Press.

Borjas, George. 2005. Labor Economics. New York: McGraw-Hill.

Brynjolfsson, Erik and Andrew McAfee. 2014. The Second Machine Age. Work, Progress, and Prosperity in a Time of Brilliant Technologies. New York: Norton.

Cahuc, Pierre and Francis Kramarz. 2004. De la précarité à la mobilité: vers une sécurité sociale professionnelle. Paris: La Documentation française.

Cappelli, Peter. 1999. The New Deal at Work: Managing the Market-Driven Workforce. Boston: Harvard Business School Press.

Cardon, Vincent. 2011. Une vie à l'affiche. Sociologie du vieillissement en emploi des artistes interprètes. These de doctorat. Paris: EHESS.

Casaux-Labrunée, Lise. 2007. Le portage salarial: travail salarié ou travail indépendant? Droit social 1: $58-71$.

Caves, Richard E. 2000. Creative Industries: Contracts Between Art and Commerce. Cambridge: Harvard University Press.

Chiappori Pierre-André. 1996. Risque et assurance. Paris: Flammarion 
Christopherson, Susan and Michael Storper. 1989. The effects of flexible specialization on industrial politics and the labor market: the motion picture industry. Industrial and Labor Relations Review 42(3): 331-347.

Compendium: Cultural Policies and Trends in Europe. 2012. Strasbourg: Council of Europe. http://www. culturalpolicies.net/web/index.php (12.08. 2012)

DCMS (Department of Culture, Media and Sport). 1998. Creative Industries Mapping Document. London: DCMS.

DCMS (Department of Culture, Media and Sport). 2008. Creative Britain: New Talents for the New Economy. London: DCMS.

Debeauvais, Rémi, Pierre-Michel Menger, Janine Rannou, Stéphane Vari, and Benoît Laplante. 1997. Le Spectacle Vivant. Paris: La Documentation française.

DiMaggio, Paul (ed.). 2001. The Twenty-First-Century Firm. Changing Economic Organization in International Perspective. Princeton: Princeton University Press.

Dokko, Jane, Megan Mumford, and Diane Withmore Schanzenbach. 2015. Workers and the Online Gig Economy. Washington: Brookings.

Drèze, Jacques. 1987. Essays on Economic Decisions under Uncertainty. Cambridge: Cambridge University Press.

Dupuy, Yves and Françoise Larré. 1998. Entre salariat et travail indépendant, les formes hybrides de mobilisation du travail. Travail et emploi 77(1): 1-14.

Eurofound. 2012. Fifth European Working Conditions Survey. Luxembourg: Publications Office of the European Union.

Faulkner, Robert and Andy Anderson. 1987. Short term projects and emergent careers: evidence from Hollywood. American Journal of Sociology 92(4): 879-909.

Freidson, Eliot. 1986. Professional Powers. Chicago: The University of Chicago Press.

Freidson, Eliot. 1994. Professionalism Reborn. Cambridge: Polity Press.

Gazier, Bernard, Claude Picart, and Claude Minni. 2016. La diversité des formes d'emploi. Paris: Conseil national de l'information statistique.

George, Elizabeth and Prithviraj Chattopadhyay. 2005. One Foot in Each Camp: The Dual Identification of Contract Workers. Administrative Science Quarterly 50(1): 68-99.

Grégoire, Mathieu. 2013. Les intermittents du spectacle : Enjeux d'un siècle de luttes (de 1919 à nos jours). Paris: La Dispute.

Harris, Seth D. and Alan B. Krueger. 2015. A Proposal for Modernizing Labor Laws for Twenty-FirstCentury Work: The "Independent Worker". Washington: Brookings.

Hesmondhalgh, David and Sarah Baker. 2010. "A very complicated version of freedom": Conditions and experiences of creative labor in three cultural industries. Poetics 38(1): 4-20.

Hesmondhalgh, David and Andy Pratt. 2005. The cultural industries and cultural policy. Special Issue. International Journal of Cultural Policy 11(1): 1-13.

Hundley, Greg. 2001. Why and when are the self-employed more satisfied with their work? Industrial Relations 40(2): 293-317.

Jencks, Christopher and Lee Rainwater. 1988. What Is a Good Job? A New Measure of Labor Market Success. American Journal of Sociology 93(6): 1322-1357.

Kalleberg, Arne. 2000. Nonstandard employment relations: part-time, temporary and contract work. Annual Review of Sociology 26: 341-365.

Kanter, Rosabeth M. 1986. Careers and the wealth of nations: a macro-perspective on the structure and implications for career forms. Pp. 506-521, in Michael B. Arthur, Douglas T. Hall, and Barbara S. Lawrence (eds). Handbook of career theory. Cambridge: Cambridge University Press. 
Katz, Lawrence F. and Alan B. Krueger. 2016. The Rise and Nature of Alternative Work Arrangements in the United States, 1995-2015. Cambridge: NBER Working Paper 22667.

Keune, Maarten and Amparo Serrano (eds.). 2014. Deconstructing Flexicurity and Developing Alternative Approaches. London: Routledge.

Kunda, Gideon, Stephen R. Barley, and James Evans, 2002. Why Do Contractors Contract? The Experience of Highly Skilled Technical Professionals in a Contingent Labor Market. Industrial and Labor Relations Review 55(2): 234-261.

Langeard, Chloé. 2013. Les intermittents en scènes: Travail, action collective et engagement individuel. Rennes: Presses Universitaires de Rennes.

Lenoir, Christian and François Schechter. 2011. L'avenir et les voies de régulation

du portage salarial. Paris: Inspection Générale des Affaires Sociales.

Marchika, Colin, Janine Rannou, and Ionela Roharik. 2008. Syndicalisme et précarité, le cas des artistes salariés intermittents. Paris: Rapport pour la Confédération générale du travail et l'Institut de recherches économiques et sociales.

Marshall, Alfred. 1947. Principles of Economics, 8th ed. New York: MacMillan.

Menger, Pierre-Michel. 2004. L'employeur, le salarié et l'assureur dans l'hyperflexibilité contractuelle: les intermittents du spectacle. Droit Social 9-10:825-833.

Menger, Pierre-Michel. 2011. Les intermittents du spectacle. Sociologie du travail flexible. Paris: Éditions de l'EHESS.

Menger, Pierre-Michel. 2014a. The Economics of Creativity. Cambridge: Harvard University Press.

Menger, Pierre-Michel. 2014b. European cultural policies and the "creative industries" turn. Pp. 479-492 in Kerry Thomas and Janet Chan (eds). Handbook of Research on Creativity. Cheltenham: Edward Elgar.

Menger, Pierre-Michel and Marc Gurgand. 1996. Work and Compensated Unemployment in the Performing Arts. Exogenous and Endogenous Uncertainty in the Artistic Labor Market. Pp. 347-381, in Victor Ginsburgh and Pierre-Michel Menger (eds.). Economics of the Arts. Amsterdam: Elsevier.

Menger, Pierre-Michel, Pascaline Costa, Danièle Hanet et Colin Marchika. 2007. Les activités de portage salarial: une analyse socio-économique. Pp. 11-43, in Lise Casaux-Labrunée (dir.). Le portage salarial. Fraude ou nouvelle forme d'organisation du travail? Paris: Wolters Kluwer.

Morin, Marie-Laure, Yves Dupuy, Françoise Larré, and Sophie Sublet. 1999. Prestation de travail et activité de service. Paris: La Documentation française.

Oakley, Kate. 2009. The disappearing arts: creativity and innovation after the creative industries. International Journal of Cultural Policy 15(4): 403-413.

OECD. 2016. OECD Employment Outlook 2016. Paris: OECD Publishing.

Picart, Claude. 2014. Une rotation de la main-d'œuvre presque quintuplée en 30 ans: plus qu'un essor des formes particulières d'emploi, un profond changement de leur usage. Pp. 29-45, in Emploi et salaires. Paris: INSEE.

Pilmis, Olivier. 2013. Lintermittence au travail. Une sociologie des marchés de la pige et de l'art dramatique. Paris: Economica.

Piore, Michael J. and Charles Sabel. 1984. The Second Industrial Divide. New York: Basic Books.

Potts, Jason. 2011. Creative Industries and Economic Evolution. Cheltenham: Edward Elgar.

Pratt, Andy and Paul Jeffcut (eds.). 2009. Creativity, Innovation and the Cultural Economy. London: Routledge.

Rannou, Janine. 1997. Les carrières des intermittents techniques de l'audiovisuel et des spectacles. De l'individu à la communauté de métier. Paris: Ministère de la Culture, Observatoire de l'emploi culturel.

Sarfatti Larson, Magali. 1977. The Rise of Professionalism. Berkeley and Los Angeles: University of California Press. 
Schmid, Günther. 2015. Sharing Risks of Labour Market Transitions: Toward a System of Employment Insurance. British Journal of Industrial Relations 53(1): 70-93.

Sinigaglia, Jeremy. 2012. Artistes, intermittents, précaires en lutte : Retour sur une mobilisation paradoxale. Nancy: Presses Universitaires de Nancy.

Smith, Vicky. 1997. New forms of work organization. Annual Review of Sociology 23: 315-339.

Stinchcombe, Arthur L. 1959. Bureaucratic and Craft Administration of Production. Administrative Science Quarterly 4(2): 168-187.

Topel, Robert and Finis. Welch. 1980. Unemployment Insurance: Survey and Extensions. Economica 47: 351-379.

Unédic. 2013a. Unemployment Insurance in 2013. Annual Report. Paris : Unédic.

Unédic. 2013b. L'activité réduite. La croissance continue de l'activité réduite recouvre des réalités et des publics différents. Une étude de l'Unédic. Paris: Unédic.

Unédic. 2016. L'assurance chômage. Dossier de référence de la négociation. Paris: Unédic.

Williamson Oliver E. 1986. Economic Organization. Firms, Markets and Policy Control. Brighton: Wheatsheaf Books.

\section{Appendix 1 The French performing arts unemployment insurance scheme}

Unemployment insurance for the performing arts and media industry adapts the French general UI program to the contingent work frame that prevails in these arts: Each intermittent worker active in the field - whether an artist or a technician or a clerical worker - meets the UI eligibility criteria when he performs enough hours of work for employers considered (by conventional agreement) as belonging to that sector.

Like for UI systems in most countries, eligibility conditions require a minimum threshold amount of work over a given period. In the arts, only those who have worked a minimum of 507 hours in a given twelve months period qualify. ${ }^{14}$ The more hours are accumulated, the longer the duration of the entitlement to compensation. The record of past job applications helps to compute the level of daily UI benefits a worker will receive over the period.

This specific UI scheme is financed through payroll taxes from employees as well as from employers. Since it belongs to the whole French UI program, the deficits it has shown for several years are made up by the general UI Fund, i.e. covered by contributions collected from the whole community of employers and employees in the private sector of the economy. Many attempts to reform its rules have been made in order to slow down this rising deficit and eventually restore the financial situation. They all failed more or less rapidly, while arousing each time huge protests by the unions and collusive manoeuvres by the employers to bring their interests in line with those of their employees.

14 New rules were adopted in the 2004 reform to shorten to 10 months or 10.5 months the time required to reach that threshold, but these rules were abolished in 2016. 